Creative Commons User License: CC BY-NC-ND

Abstracted by: EBSCOhost, Electronic Journals Service (EJS),

Google Scholar, Journal Seek, Scientific Commons,

Food and Agricultural Organization (FAO), CABI and Scopus

http://eoi.citefactor.org/10.11226/v25i1
Journal of Agricultural Extension

Vol. 25 (1) January, 2021

ISSN(e): 24086851; ISSN(Print); 1119944X

http://journal.aesonnigeria.org

http://www.ajol.info/index.php/jae

Email: editorinchief@aesonnigeria.org

\title{
Effects of Farmer-Herder Conflicts on Rural Households Food Security in Gombe State, Nigeria \\ https://dx.doi.org/10.4314/jae.v25i1.2
}

\section{Sani Madi Yakubu}

Department of Agricultural Extension and Management, Federal College of Horticulture

Dadin Kowa, Gombe State. E-mail: Sanimadiyakubu2015@gmail.com, Ph

Number:+2348030669062.

\section{Micheal Wandzu Musa}

Department of Agricultural Extension and Rural Development, Ahmadu Bello University, Zaria, Kaduna State. E-mail: mikemusa@yahoo.com, Phone Number, +2348169027667.

\section{Tologbonse Emmanuel Bamidele}

Department of Agricultural Extension and Rural Development, Ahmadu Bello University, Zaria, Kaduna State. E-mail: deletologbonse@gmail.com, Phone Number +2348036426505 .

\section{Mahmoud Babawuro Ali}

Department of Horticultural Technology, Federal College of Horticulture Dadin Kowa, Gombe State. E-mail: babawuroalikumo@gmail.com, Phone Number, +2348037278642

\section{Muhammed Tukur Bappah}

Department of Agricultural Extension and Management, Federal College of Horticulture Dadin Kowa, Gombe State. E-mail: bappamuhammedtk@gmail.com Phone Number:+2347031203457.

\section{Raji Tunde Munir}

Department of Agricultural Extension and Rural Development, Ahmadu Bello University, Zaria, Kaduna State. E-mail: rajtunde@yahoo.com, Phone Number +2348033483951.

\section{Abubakar Manuwa \\ Department of Agricultural Extension and Rural Development, Ahmadu Bello University, Zaria, Kaduna State. E-mail: abubakarmanuwa@gmail.com Phone Number, $+2348029523235$}

\section{Abstract}

The study examined the effects of farmer-herder conflicts on rural households' food security in Gombe State, Nigeria. Primary data were collected using structured questionnaire and focus group discussion among 118 farmers and 112 herders. Percentage, tobit and logit regression models were used in analysing the data. The result showed that, household size and education, farm size and cattle route encroachment were the major causes of the conflict. In addition, killing of stray cattle, population growth, rape and sexual harassment were all responsible to farmer-herder conflict with different marginal effects. The study revealed $59.3 \%$ of the farmers and $31.3 \%$ of the herders, had food insecure with moderate hunger, while $43.7 \%$ of the farmers and $66.1 \%$ of the 
herders had food insecurity with severe hunger. Selling of grazing areas, corrupt practices by traditional rulers are some of the constraints that affects conflict management. There is need to create a platform that will bring all stakeholders together on a quarterly basis in order to have an interaction and to employ extension agents to serve as an intermediary between farmers and herders. There is need for the law makers to revisit the existing 1964 grazing reserves act and 1978 land tenure act so as to give room to accommodate land ownership, usage and control for the competing parties. This may help in reducing the intensity of the conflict. Finally, there is need for the adoption of some mitigating strategies such as alternative dispute resolutions, arrest and prosecution of offenders to manage the reoccurrences of conflicts.

Keywords: Farmer-herder conflicts, rural households, food security status.

\section{Introduction}

Agricultural production provides the means of livelihood and economic sustenance for the majority of Nigerians population. Farmers and herders make significant contributions in meeting the nutritional needs of the country and thus contributing to food security of households (Onuoha, and Ezirim, 2015). Food security at the individual, household, national, regional and global levels is achieved when all people, at all times, have physical and economic access to sufficient, safe and nutritious food to meet their dietary needs for active and healthy life. Food insecurity exists when people do not have adequate physical and economic access to food, (Food and Agricultural Organisation (FAO), 2015).

Recently, there have been a lot of concerns expressed over the looming danger of food crisis in many nations, including Nigeria. The main goal of food security, is for individuals to obtain adequate food needed at all time, and to be able to utilize the food to meet the body needs. The World Bank identified four pillars underpinning food security, as food availability, food accessibility, food utilization and food stability (FAO, 2015). In recent years, Nigeria have witnessed series of violent communal clashes arising from the activities of the herders who move about on a daily basis with their cattle in search of water and green pastures (Suleiman, 2015). Consequently, many farmers and herders have lost their lives, while others have experienced declining production in their crops and herds (Suleiman, 2015).

Conflict has been one of the stumbling blocks and a major threat to world peace today. Conflict is perceived as a serious disagreement or argument about something important that leads to the outbreak of law and order (Collins, 2016). Conflict is a struggle or contest between people with opposing needs, ideas, values and goals (Dietz and Albert, 2016). According to Oyetade (2017), access to water and grazing land has become more competitive and has led to farmers and herders into arguments on a regular basis. This is a worrisome trend because both have coexisted interdependently for centuries, sharing the same fields for farming and grazing with a manageable level of tolerance and accommodation.

Historically, conflict between farmers and herders in Nigeria existed, but recently with increase in population, as well as climatic changes, have led to cultivation of more land that is meant for grazing and cattle routes. It is important to note that these conflicts have direct effects on the food security of those involved as well as the country at large. Conflicts disrupts and threatens the peaceful coexistence of different ethnics' groups and sustainability of agricultural production in Nigeria (Moritz, 2016). 
This had led to damage of crops, attacks on cattle, destruction of properties, killings of live and cattle rustling in Gombe State. It is reported that climatic change, population growth, environmental degradation, government policies and insurgency activities are some of the major trigger of conflicts and violence between farmers and herders (Suleiman, 2015). However, little or inadequate information have been documented, in respect to effects of farmer-herder conflicts on food security of rural households especially in Gombe State. As a result of the increasing trend of the conflicts in the State, it poses a key challenge and call for an in-depth analysis of its effects on food security among rural households. It has not been sufficiently documented on the specific or inter-play of factors influencing farmer-herder conflicts in the study area. Furthermore, it is not well known about the mitigation strategies employed in the management of farmer-herder conflicts in the study area, neither of the effectiveness or constraints of such management strategies. Given these backgrounds, this study addresses the following research objectives:

\section{Objectives of the Study}

The study examined the effects of farmer-herder conflicts on rural households' food security in Gombe State, Nigeria. The specific objectives of the study were to:

i. determine the socio-economic characteristics, institutional and environmental factors influencing farmer-herder conflicts;

ii. examine the effects of farmer-herder conflicts on food security of rural households and

iii. identify the mitigation strategies associated with the management of the farmer-herder conflicts.

\section{Methodology}

The study was carried out in Gombe State, located at the center of the north eastern part of Nigeria between latitude $9^{\circ} 30$ and $12^{\circ} 30^{\circ} \mathrm{N}$, longitude $8^{\circ} 5$ and $11^{\circ} 45 \mathrm{E}$. The State is made up of 11 local government areas (LGAs). It has a total land area of 20,265 Square kilometres with an estimated population size of $(2,857,042)$ in 2006 National Population Commission [NPC], (2006) and a projected population of $(4,195,662)$ in 2019 . The target population for the study were farmers and herders. A multi-stage sampling procedure was used to select respondents for the study. The first stage involved the purposive selection of three local government areas, one each from the three agricultural zone. (Billiri in the South, Dukku in the North and Yamaltu Deba in the Central Zones). The selection was based on the frequent occurrence of farmerherder conflicts in the study area. The LGAs selected had recorded frequent clashes between farmers and herders. The second stage involved stratified random sampling of 3 villages, from each of the 3 selected LGAs giving a total of 9 village communities, (Wade, Kuri, Dadin Kowa from Y/Deba LGA, Maltawo, Jamari, Maru from Dukku LGA and Tudu, Ayaba, Laushidadi from Billiri LGA). A total number of 276 farmers were selected, while 267 herders were equally selected, to give a total sample frame of 543 respondents for both the farmers and herders. A sample size of 230 respondents were used, 118 farmers and 112 herders respectively. Primary data were obtained using semi-structured questionnaire, interview schedule and focus group discussion (FGD). Percentages, mean and standard deviation were used to identify the mitigation strategies associated with the management of farmer-herder conflicts, while tobit and logit statistical tools were employed to determine the factors influencing farmer-herder conflicts and to examine the effects of farmer-herder conflicts on food security of rural households.. 


\section{Model Specification}

\section{Logit regression model}

$\mathrm{Y}=\beta_{0}+\beta_{1} \mathrm{X}_{1}+\beta_{2} \mathrm{X}_{2}+\beta_{3} \mathrm{X}_{3}+\beta_{4} \mathrm{X}_{4}+\beta_{5} \mathrm{X}_{5}+\beta_{6} \mathrm{X}_{6}+\beta_{7} \mathrm{X}_{7}+\beta_{8} \mathrm{X}_{8}+\mathrm{U} ;$

Where:

$\mathrm{Y}=$ Rural households food security $\left(\begin{array}{c}\mathrm{Y}=0 \text { for food secure } \\ \mathrm{Y}=1 \text { for food insecure }\end{array}\right)$

$\mathrm{X}_{1}=$ Interpersonal dispute/clashes (numbers of personal clashes)

$\mathrm{X}_{2}=$ Group disputes/clashes (numbers of group clashes)

$X_{3}=$ Violent confrontation (numbers of violent confronted)

$\mathrm{X}_{4}=$ Destruction of properties (amount of properties destructed)

$X_{5}=$ Maiming and killing (numbers of family member injured or lost)

$X_{6}=$ Cattle rustling (numbers of cattle stole)

$\mathrm{X}_{7}=$ Killing of stray cattle's (numbers of cattle lost)

$X_{8}=$ Crop damage by cattle encroachment (bags of crop destroyed)

$\beta_{0}=$ Constant

$\beta_{1}-\beta_{8}=$ Regression coefficients

$U=$ Error term

\section{Tobit regression model}

$\mathrm{Yi}^{*}=\beta_{o}+\beta_{1}+X_{1} \beta_{2}+X_{2} \beta_{3}+X_{3} \beta_{4}+X_{4} \beta_{5}+X_{5} \beta_{6}+X_{6} \beta_{7}+X_{7} \beta_{8}+X_{8} \beta_{9}+X_{9} \beta_{10}+$ $X_{10} \beta_{11}+X_{11} X_{12}+\beta_{12} \beta_{13}+X_{13} \beta_{14}+X_{14} \beta_{15}+X_{15} \beta_{16}+X_{16} \beta_{17}+$ $X_{17} \ldots \ldots \ldots \ldots \ldots \ldots . .2 .4 .2$.

17.

Where:

$\mathrm{Yi}^{*}=$ Farmer-Herder conflicts.

$\mathrm{X}_{1}=$ Age (in years)

$X_{2}=\operatorname{Sex}($ male $=1$, female $=0)$

$X_{3}=$ Marital Status (single $=0$, married $=1$, divorce $=2$, widow $=3$ )

$\mathrm{X}_{4}=$ Higher Educational Levels (years spent)

$\mathrm{X}_{5}=$ Households Size (numbers of individual)

$X_{6}=$ Farm Size (numbers of hectare)

$X_{7}=$ Herds Size (numbers of cattle)

$\mathrm{X}_{8}=$ Farming Experience (years in farming)

$X_{9}=$ Herding Experience (years in herding)

$X_{10}=$ Membership of Association (years spent as a member)

$X_{11}=$ Government Policy $(1=$ Yes, $0=$ No $)$

$X_{12}=$ Role of Traditional Rulers $(1=$ Yes, $0=$ No $)$

$\mathrm{X}_{13}=$ Extension Contact (numbers of extension visit in a year)

$X_{14}=$ Cattle Routes (5-point Liker scale)

$X_{15}=$ Grazing Reserves (5-point Liker scale)

$X_{16}=$ Water Resources (5-point Liker scale)

$\mathrm{X}_{17}=$ Vegetation Cover (5-point Liker scale)

$a=$ Constant

$\beta_{1-} \beta_{17}=$ regression coefficients

$\mathrm{e}=$ error term 


\section{Results and Discussion \\ Factors Influencing Farmer-Herder Conflicts}

The log likelihood value was statistically significant on the basis of the F-test at 1 percent level of probability which implies that all the coefficients in the model were jointly significant. The coefficient of household size was positive sign and statistically significant of probability. It's an evident from the study that large households are more prone to farmer-herder conflicts than those with fewer household.

While the coefficient of education had an inverse relationship with conflict and statistically significant, thus suggesting that the higher the educational level of the household, the more they avert/avoid conflict compare to non-educated people. Educated person may be more open to dialogue during conflicts. The coefficient of farm size also had an inverse relationship with conflict and statistically significant at 1 percent level. This may be due to high pressure on land resulted from increase in population vis-à-vis the traditional land tenure of inheritance. Farming on the cattle routes was positive sign and statistically significant. This implies that as farmers continue farming on the cattle routes this may cause farmer-herder conflicts. The positive relationship indicates that the more the cattle routes are encroached the more the probability to engage in conflict between farmers and the herders. This agrees with the assertion by Yahaya (2018) that land encroachment is among the causes of farmer-herder conflicts. Nyong (2015), also revealed that it is natural for the farmers to encroach on marginal lands that had been the traditional pasture routes for the cattle.

This has therefore heightened struggle between livestock and agricultural production which, often escalate the conflicts. 
Table 1: Factors influencing farmer-herder conflicts

\begin{tabular}{lccc}
\hline Variables & Coefficient & Std. Err. & T \\
\hline Age & 0.001101 & 0.00153 & 0.72 \\
Sex & -0.02968 & 0.044071 & -0.67 \\
Marital status & -0.00025 & 0.025776 & -0.01 \\
Household size & 0.006957 & 0.003349 & $2.08^{* *}$ \\
Education & -0.02762 & 0.012347 & $-2.24^{* *}$ \\
Farm size & -0.01709 & 0.006787 & $-2.52^{* * *}$ \\
Farming experience & -0.00122 & 0.001516 & -0.8 \\
Cooperative membership & -0.00178 & 0.001526 & -1.17 \\
Extension contact & -0.01065 & 0.012233 & -0.87 \\
Herd size & -0.00025 & 0.000178 & -1.39 \\
Decline in grassland & -0.10091 & 0.074595 & -1.35 \\
Misuse of water bodies in the area & -0.00135 & 0.045183 & -0.03 \\
Farming on the grazing reserves & 0.064896 & 0.050494 & 1.29 \\
Farming on the cattle routes & 0.135748 & 0.046381 & $2.93^{* * *}$ \\
Low rainfall in the region & -0.05155 & 0.060611 & -0.85 \\
High incidence of desertification & -0.03506 & 0.042125 & -0.83 \\
Cons & 0.195921 & 0.395053 & 0.5 \\
Sigma & 0.1635471 & 0.0081739 & 20.00 \\
No of observation, 230; LR chi ${ }^{*}$ (16), 75.56; Prob > chi ${ }^{2}, 0.0000 ;$ Log & \\
likelihood.51.046 & & &
\end{tabular}

${ }^{\star * *} \mathrm{P}<0.01,{ }^{* *} \mathrm{P}<0.05,{ }^{*} \mathrm{P}<0.10$, Std Err. $=$ Standard Error, Coef $=$ Coefficient.

\section{Effects of Farmer-Herder Conflicts on Rural Households Food Availability}

Entries in Figure 1 show that $7.0 \%$ of the respondents opined that food availability is fairly adequate, $26.0 \%$ of the respondents stated that food availability is not adequate, while $23.0 \%$ were of the opinion that food security is poor, while $43.0 \%$ posited that the situation is very poor. The result in Figure 1 from the foregoing, about $92.0 \%$ opined that the farmer-herder conflicts have affected the availability of food supply in the study areas. This corroborates reports by the National Emergency Management Agency [NEMA], (2018), of the grave food insecurity situation in the north eastern zone of the country. 


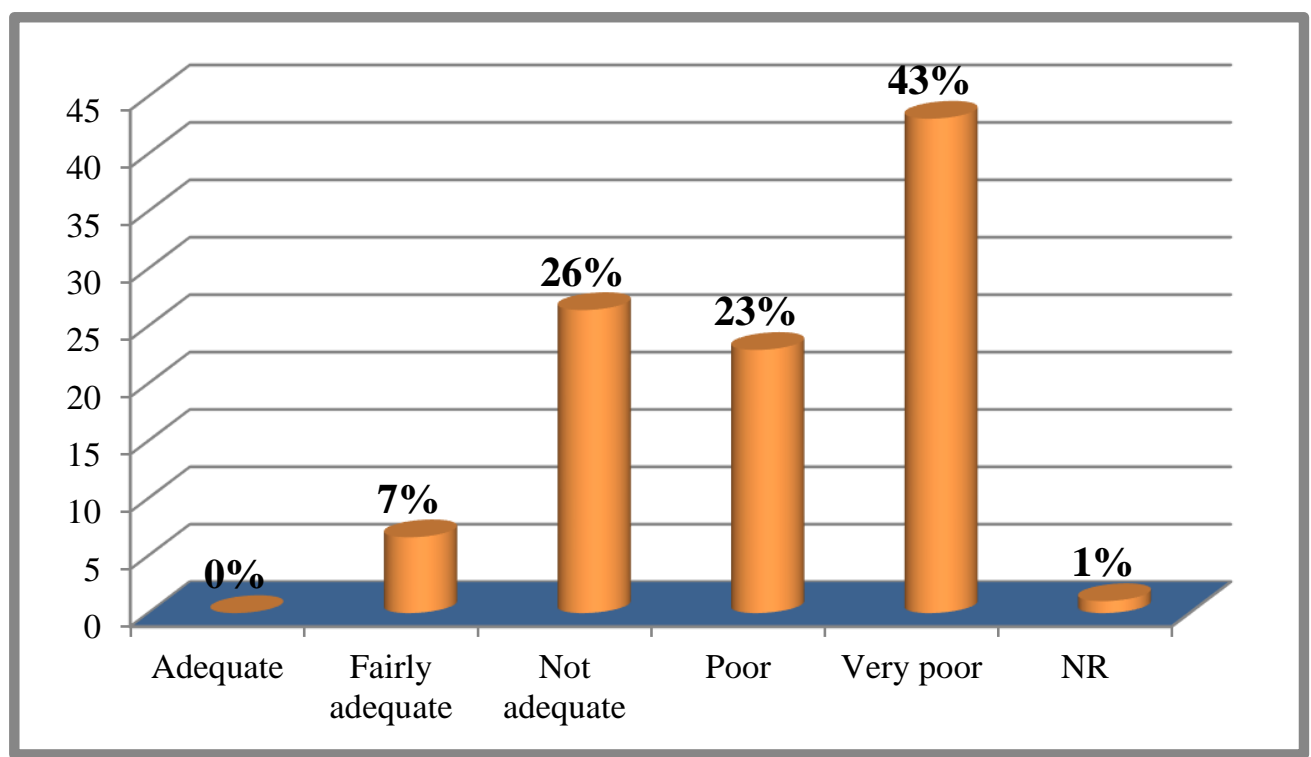

Figure 1: Effects of conflict on food availability

\section{Food Security Status of United State Development Agency}

Result in Figure 2 shows that, the farmers were more with food insecurity without hunger than the herders but fewer than their counterparts in terms of food insecurity with moderate hunger and food insecurity with severe hunger. Majority of the respondents were food insecurity with severe hunger.

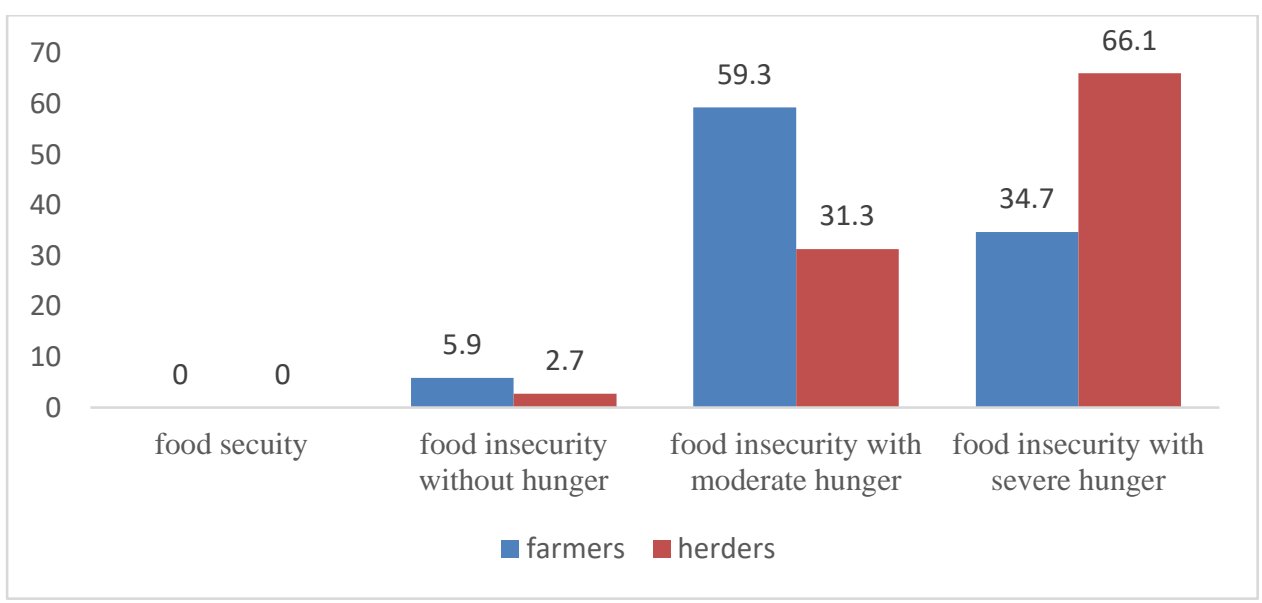

Figure 2: Effects of conflict on their food security status

\section{Effects of Farmer-Herder Conflicts on Food Security of Rural Households}

Table 2 shows that killing of stray cattle, increase in population, rap and sexual harassment were statistically significant determinants of farmer-herder conflicts on food security of rural households. Killing of stray cattle had a negative sign and statistically significant at 5 percent level. Implying their inverse relationship to the respondents' involvement in conflict. An increase in killing of stray cattle could lead to an increase in conflict between farmers and herders. The marginal effect of 0.78 shows that, killing of stray cattle increases the probability of conflict by $7.8 \%$. This finding is in line with that of Bello (2015), that killing of stray cattle by farmers is among the causes of farmer-herder conflicts. 
Increase in population has a direct relationship with conflict and statistically significant at 10 percent level. Implying that an increase in population will lead to farmer-herder conflicts. The marginal effect of 0.68 shows that continue increase in population, increases the probability of conflict by $6.8 \%$. This is in line with the findings from Eje et al., (2016), revealed that crops damaged is due to encroachment of grazing routes by the farmers as a result of increase in population this have led to conflicts between farmers and herders.

Raping and sexual harassment has a direct relationship with farmer-herder conflicts and statistically significant at 10 percent level. Implying that continue increase in raping and sexual harassment will lead to an increase in farmer-herder conflicts. The marginal effects of 0.324 shows that an increase in raping and sexual harassment, increases the probability of conflicts by $32.4 \%$. This is line with the findings from Eje et al., (2016), that, the harassment of female was rated by both farmers and herders as having caused conflicts.

Table 2: Effects of farmer-herder conflicts on food security of rural households

\begin{tabular}{|c|c|c|c|c|}
\hline Variables & Coefficient & Std. Err. & $\mathbf{Z}$ & $\begin{array}{c}\text { Marginal } \\
\text { effect }\end{array}$ \\
\hline Crop damage by cattle & 0.114 & 0.216 & 0.53 & 0.027 \\
\hline Land Encroachment & -0.020 & 0.137 & -0.15 & -0.005 \\
\hline Inadequate grazing reserves & -0.269 & 0.468 & -0.58 & -0.063 \\
\hline Lack of access to water point & -0.129 & 0.133 & -0.97 & -0.03 \\
\hline Killing of stray cattle & $-0.332^{* *}$ & 0.137 & -2.42 & -0.078 \\
\hline Pollution of water points & 0.314 & 0.376 & 0.83 & 0.073 \\
\hline $\begin{array}{l}\text { Disregard for rules and } \\
\text { regulation }\end{array}$ & -0.603 & 0.544 & -1.11 & -0.140 \\
\hline Increase in population & $0.291^{*}$ & 0.148 & 1.96 & 0.068 \\
\hline Environmental degradation & -0.136 & 0.464 & -0.29 & -0.032 \\
\hline Boko haram insurgency & -0.847 & 0.518 & -1.64 & -0.197 \\
\hline Government policy & 0.082 & 0.397 & 0.21 & 0.019 \\
\hline $\begin{array}{l}\text { Spraying of grass with } \\
\text { chemicals }\end{array}$ & 0.072 & 0.159 & 0.45 & 0.017 \\
\hline Raping and sexual harassment & $\begin{aligned} 1.392^{*} \\
-0.602\end{aligned}$ & $\begin{array}{l}0.722 \\
4.303\end{array}$ & $\begin{array}{r}1.93 \\
-0.14\end{array}$ & 0.324 \\
\hline \multicolumn{5}{|c|}{ No of observation, 230; LR chi (16), 37.04; Prob > chi², 0.0004; Log likelihood, - } \\
\hline
\end{tabular}

\section{Mitigation Strategies Associated with Farmer-Herder Conflicts}

Table 3 shows the various methods of conflict resolution commonly employed in resolving the farmer-herder conflicts in the study areas, the result shows that $99.1 \%$ indicated that arrest and prosecution as the most popular method of managing conflicts followed by alternative dispute resolution with $94.4 \%$ and $92.8 \%$ of the respondents reports that verbal warning and provision of relief materials respectively as a mitigating strategy that were used in resolving farmer-herder conflicts. 
Table 3: Mitigation strategies associated with farmer-herder conflicts

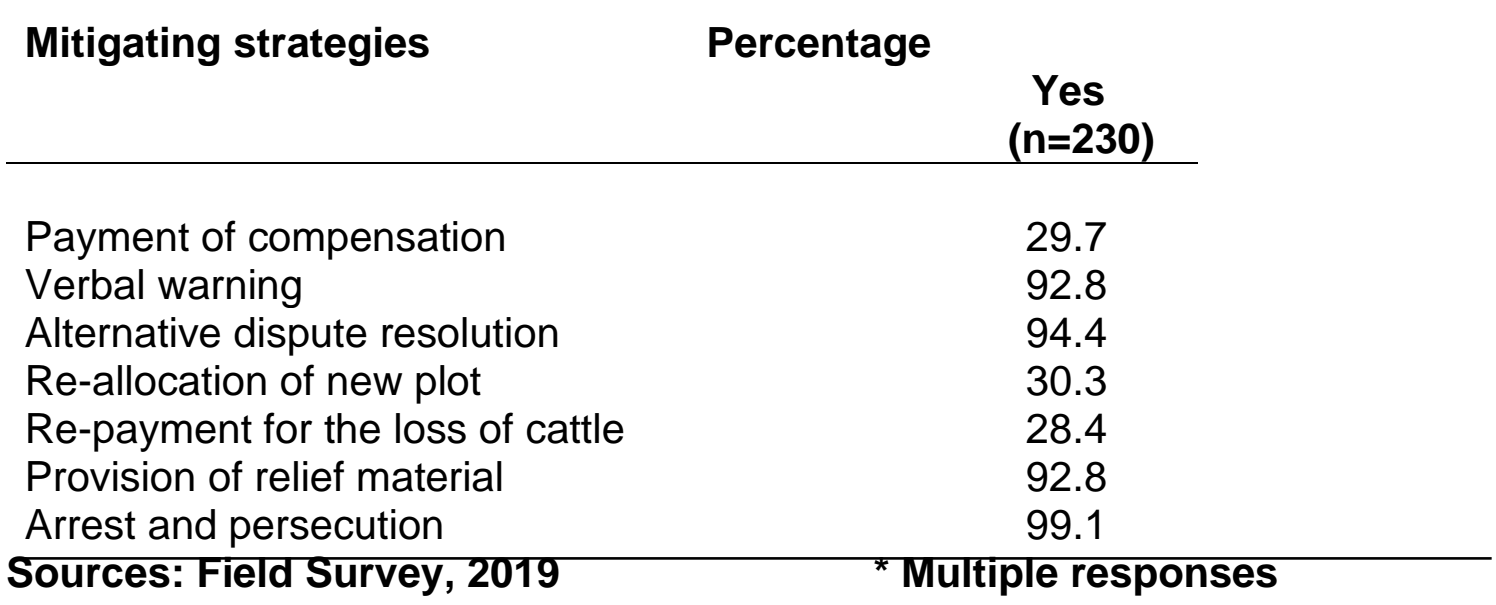

\section{Conclusion and Recommendations}

Farmer-herder conflicts have drastically reduced the availability of food supply as well as the income of rural households. Three key factors are responsible for farmer-herder conflicts in the study areas, these are; killing of stray cattle, increase in population, raping and sexual harassment by the parties. This issue has consistently been in the forefront of most of the media outlet of the nation. As such, farmers view cattle routes and grazing reserves as land not possessed by anyone and can therefore be freely encroached. The herders on the other hand, has the belief that feeding his cattle at whatever circumstances is a superior and uncompromising right given to him by nature and these had led to clashes between the competing parties.

Village extension agents should be employed to serve as intermediary between the farmers and herders. The need to create a platform that will bring all stakeholders together on a quarterly basis. Government should investigate the report of traditional rulers and local government official who engaged in corrupt practices of selling grazing areas and cattle routes, in order to take necessary action to prevents its reoccurrences. There is the need to revisits the existing 1964 grazing reserves act and 1978 land tenure act so as to accommodate land ownership, usage and control by farmers and herders. There is the needs to adopt some mitigating strategies such as alternative dispute resolutions, provision of relief materials, arrest and prosecution of the offenders, in managing the intensity of the conflicts.

\section{References}

Bello, A. S. (2015). Herdsmen and farmers conflicts in North-Eastern Nigeria, causes, repercussions and resolutions. Academic Journal of Interdisciplinary Studies, 2(5): 129-139.

Collins, G., Maxwell, D., Watkins, B. and Wheeler, R. (2016). The Coping Strategies Index, a Tool for Rapidly Measuring Food Security and Impact of Food Aid Programs in Emergencies. Food Agriculture Organisation (FAO), International Workshop on Food Security in Complex Emergencies Tivoli, 632 pp.

Dietz, T. S. S. and Albert, M. (2016). The European union and border conflict. The transformation power of integration, International Journal for United Organizations, 60(3): 563-593.

Eje, T. I., Angai, I. A., Abdullahi, Y. B., Eje, P. O., Wudaba, L. E. and Ishaku, N. (2016). Pattern and impact of conflicts between farmers and herders in Riyom Local Government 
Plateau State, Nigeria department of political sciences university of Jos, Nigeria. International Journal of Humanities and Social Studies, 2(2): 323-333

Food and Agricultural Organisation (FAO), (2015). Agriculture and Development Economics Division, Food Security. FAO Policy Brief Issue, 202 pp.

Food and Agricultural Organisation (FAO), (2015). Voices of the Hungry Website. http://www.fao.org/economic, 542 pp.

Moritz, M. (2016). Understanding herder-farmer conflicts in West Africa. outline of a procession approach. Journal of Society for Applied Anthropology in Human Organization, 69(2): 765-769.

National Emergency Management Agency (NEMA), (2017). Provision of Relief Material to the Victims of Insurgency in North Eastern Nigeria, Repository Bulletin, 94-97 pp.

National Population Commission (NPC) (2006). Population and Development Review. 33(1): 206-210.

Nwaiwu, J. N. (2015). Impact of political environment on business performance of multinational companies in Nigeria. An International Multidisciplinary Journal Ethiopia, 9(3): 1-10.

Olobatoke, R. and Omowumi, A. (2017). Effects of fulani-herder's intrusion on the economic livelihood of farmers in Yagba East Local Government Area of Kogi, State, Nigeria. DAC of Ahmadu Bello University, Kabba, Nigeria. International Journal of Agricultural Policy and Research, 2(5): 80-85.

Onuoha, F. C. and Ezirim, G. E. (2015). Climate change and national security. Journal of Agricultural Policy and Research, 1(55): 233-242

Oyetade, L. (2017). Farmers in Northern Nigeria Suffer Effects of Desertification. www.africanagricultureblog.com.

Sulaiman, H. (2015). Policy Issues in Pastoral Development in Nigeria. Paper Presented at a Conference on Pastoralism in Nigeria. Zaria, 26th-29th June.

Umeh, G. N. and Chukwu, V. A. (2015). Socio-economic perspectives to arable crop farmersherders conflict in Ebonyi North Zone, Ebonyi State. department of agricultural economics and extension, Ebonyi State, Nigeria. International journal of sciences and research, 1(1): 21-43.

Yahaya, Y. S. (2018). Perspectives on Nomads/Farmers Conflicts. A paper Presented at Zamfara State College of Education, Zamfara State, Nigeria. September $14^{\text {th }}-16^{\text {th }}$ 2008. 